\title{
Predicting the potential spatial distributions of epiphytic lichen species at the landscape scale
}

\author{
Janine BOLLIGER, Ariel BERGAMINI, Silvia STOFER, Felix KIENAST and \\ Christoph SCHEIDEGGER
}

\begin{abstract}
The potential spatial distributions of six epiphytic lichen species were assessed in Switzerland $\left(41000 \mathrm{~km}^{2}\right)$ as a function of various key climatic drivers and forest types using logistic regression models. Cetrelia cetrarioides is 'near threatened', Lobaria pulmonaria is 'vulnerable', and Graphis scripta, Hypogymnia physodes, Lecanora cadubriae, Letharia vulpina are not endangered according to the Red List assessment based on IUCN criteria. Lichen presence and absence were derived from the SwissLichens database that contains spatially explicit information on both species presence and absence.

The spatial lichen niches are predicted with $\mathrm{R}^{2}$ values between 0.5 and 0.75 and AUC values between 0.63 and 0.94 . Model evaluation shows that the models perform well.

Lichenologists reviewed the spatial predictions of lichen species on the basis of their expert knowledge and concluded that parsimonious regression models may suffice for successful prediction of the potential spatial niche distributions of epiphytic lichen species.
\end{abstract}

Key words: AUC, bioclimate, Cetrelia cetrarioides, GINI coefficient, GLM, Graphis scripta, Hypogymnia physodes, Lecanora cadubriae, Letharia vulpina, Lobaria pulmonaria, predictive distribution model, ROC, Switzerland

\section{Introduction}

Data availability on species distributions at the landscape-scale is often limited, as the collection of quality data is costly (Bowker 2000), or limited for infrequent, inconspicuous, or less broadly known taxa (Berg et al. 2004; Edwards et al. 2005; Martinez et al. 2006). However, when conducting landscape-scale surveys or monitoring projects for the development of effective management and conservation strategies, a sufficient quantity of data is required to estimate or model species frequencies and distributions (Maina \& Howe 2000; Edwards et al. 2005; Lavergne et al. 2005). Thus, adequate detection of species occur-

J. Bolliger, A. Bergamini, S. Stofer, F. Kienast and C. Scheidegger: Federal Research Institute WSL, Zürcherstrasse 111, CH-8903 Birmensdorf, Switzerland. Email: janine.bolliger@wsl.ch rences or abundances to derive baseline information is needed for ecological conservation or management strategies. One possible strategy involves the development of predictive models which generate potential spatial distributions of species as a function of point observations. The models yield continuous probability surfaces of species occurrence in the modelled biophysical and geographic space. Thus, although frequently restricted due to limited data availability, the approach may be important in generating and testing hypotheses about landscape-scale spatial distribution potentials of infrequent, inconspicuous, or less broadly known taxa such as lichens or bryophytes (Kadmon \& Heller 1999; Berg et al. 2004; Edwards et al. 2005; Martinez et al. 2006). Methodologically, statistical tools available to correlate species with their habitats include General Linear Models, General Additive Models, or CART models 
(Guisan \& Zimmermann 2000; Thuiller et al. 2003; Guisan \& Thuiller 2005).

It has been claimed that climate is a major driver of species distributions across Europe (Thuiller et al. 2004). Thus, climate and its variability have been widely applied in ecological research that quantifies species spatial biotic responses as a function of environmental drivers (Zimmermann \& Kienast 1999; Bolliger et al. 2000; McKenzie et al. 2003) or land-use (Easterling et al. 2001; Dirnböck et al. 2003; Dullinger et al. 2003a; Dullinger et al. $2003 \mathrm{~b}$ ). It has also been used to estimate potential spatial distributions of a variety of animal habitats and taxa, e.g., insects (Bonn \& Schröder 2001) and molluscs (Kadmon \& Heller 1999; Berg et al. 2004).

In this paper, we identify the potential spatial niche distributions of six epiphytic lichen species as a function of key climatic drivers and major forest types in Switzerland. The resulting species distribution models may be used further either to complete existing lichen surveys by identifying areas where the species has not previously been observed (Edwards et al. 2005), or to delineate species-specific, spatially explicit occurrence hotspots. Spatial niche modelling of lichen species has only rarely been done (Edwards et al. 2005; Martinez et al. 2006). Many lichen species occupy specific microenvironmental niches (e.g., rain-exposed surface of a trunk), and are known to be sensitive towards environmental change (Wirth 1992). Thus, assessing lichen-specific niche potentials is important in estimating the degree of sensitivity to change, although the poikilohydric properties of lichens may complicate modelling mainly by purely environmental variables. Four out of the six lichen species considered here are not currently threatened (Graphis scripta, Hypogymnia physodes, Lecanora cadubriae, Letharia vulpina), one is near threatened (Cetrelia cetrarioides), and one species is vulnerable (Lobaria pulmonaria) according to the Red List assessment for Switzerland following IUCN criteria (Scheidegger et al. 2002).

\section{Material and Methods}

\section{Study area}

Switzerland covers an area of approximately $41000 \mathrm{~km}^{2}$, of which $12300 \mathrm{~km}^{2}$ is forested (Statistisches Jahrbuch der Schweiz 1997). The climate is temperate humid, but there is a strong regional variation due to the effects of mountains. Conditions range from an intra-alpine dry and continental climate (Central Alps) to an oceanic regime at higher (Northern Alps, Jura Mountains) and low elevations (Plateau). The southern alpine part of Switzerland is dominated by an insubrian climate type with relatively mild and dry winters and warm-humid summers (Fig. 1).

\section{Study species}

Six lichen species were selected to provide examples of characteristic distribution ranges along altitudinal and climate gradients in Switzerland (Table 1). Lobaria pulmonaria (L.) Hoffm., and Cetrelia cetrarioides (Duby) W. Culb. \& C. Culb) represent species which occur predominantly in oceanic climates and Letharia vulpina (L.) Hue represents species occurring in continental climates. Lecanora cadubriae (Massal.) Hedl. Hypogymnia physodes (L. Nyl.) and Graphis scripta (L.) Ach. are observed across all major bioclimatic regions of Switzerland, but their distribution ranges differ with respect to altitude. Hypogymnia physodes is widespread at altitudes between 1000-1600 m asl, and Graphis scripta occurs mainly at altitudes between $600-1000 \mathrm{~m}$ a.s.1.

Data on presence/absence of lichens, or more specifically, detection/non-detection, were obtained from the SwissLichen database (Stofer et al. 2003). The data were collected between 1989 and 2000 and for each observation, the species name, coordinates, elevation, status of protection, number of specimens found, and name of most frequent hosts (tree, shrub) were recorded. The database encompasses 557 epiphytic lichen species across Switzerland selected from systematic design and non-systematic purposive sampling approaches. The design sampling is based on a stratified random sample across Switzerland and is a measure of both lichen presence and absence. Lichen observations from purposive sampling originated from non-systematic sampling performed by amateur and professional lichenologists who collected lichens in specific areas mainly for qualitative, floristic purposes. Lichen data originating from purposive sampling are thus presence only data with a strong subjective bias.

For this study, both sampling methods (systematic design and purposive) were combined. Data from the designed sampling strategy relies on plots of $500 \mathrm{~m}^{2}$ located on the $1 \mathrm{~km}$ intersections of the Swiss coordinate system. The database contains a total of 826 plots for the purpose of long-term observations. The plots were pre-stratified according to the presence of forest (two strata), altitudinal gradients (six strata) within the five major regions of Switzerland (Jura Mountains (98), Plateau (189), Northern Alps (132), Alps (336), and Southern Alps (71 sampling plots)). Within these strata, the plot selection was performed randomly. For each 


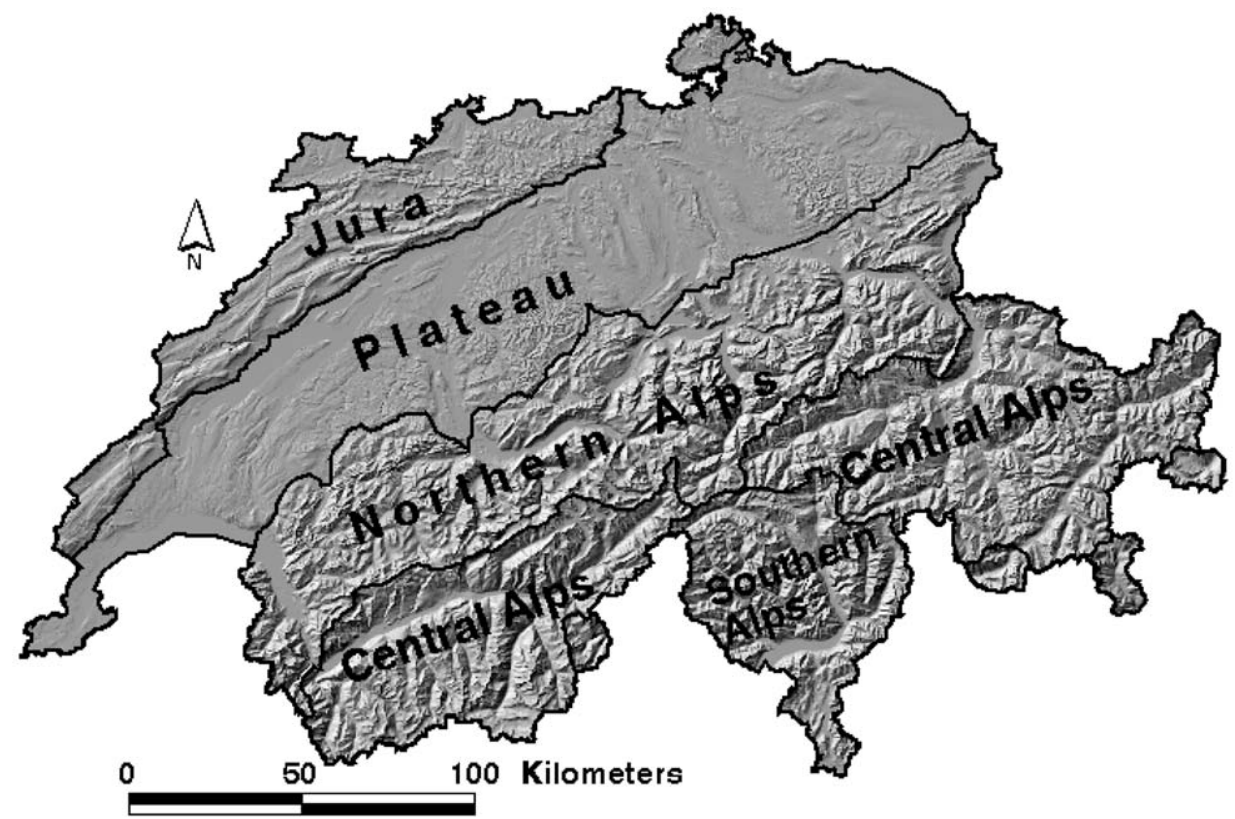

FIG. 1. The study area of Switzerland and its five major bioclimatic regions.

plot, lichen-species' presence and absence were recorded. Lichen observations derived from the purposive sampling strategy relied on a $20 \times 20 \mathrm{~km}$ grid and lichen floristic data derived from the literature. These data mirror species presence only. For a more detailed description of the sampling strategies see Dietrich et al. (2000) and Scheidegger et al. (2002).

\section{Species distribution modelling}

We used logistic regression with a logit link function to predict the spatial distribution of lichen species as a function of various climatic variables and forest types. Logistic regression is well established in ecological research and has been widely used to predict species probability surfaces from presence/absence data for species distribution modelling (Bartlein et al. 1986; Brown 1994; Mladenoff et al. 1995; Guisan et al. 1998; Bolliger et al. 2000; Guisan \& Zimmermann 2000; Guisan \& Hofer 2003; McKenzie et al. 2003). The predicted response surfaces take values of probability of presence between 0 and 1 . Low probabilities of occurrence (close to 0 ) indicate sites of potentially unsuitable ecological niches. High values (close to 1) specify potentially suitable ecological niches for the corresponding lichen species. However, probabilities of presence are no indication of species frequency, or difficulty and time requirements to successfully detect a species in a predicted habitat.

Use and limitations of species distribution modelling have been discussed elsewhere (Guisan \& Zimmermann 2000; Hampe 2004; Segurado \& Araujo 2004; Guisan \& Thuiller 2005) and will not be repeated here.

\section{Climatic variables}

Independent predictors included thermic (summer frost frequency, degree day sum) and hygric variables (yearly precipitation sum, water budget in July), as well as measures of continentality (global radiation in March and July, Gams angle) (Table 2). The variables used in this study are described in detail in Zimmermann and Kienast (1999) and Bolliger et al. (2000). All climatic variables are available as raster maps, based on spatially interpolated data from standardized meteorological records derived from the national network and digital elevation models (DEM) on a $25 \mathrm{~m}$ resolution. Monthly averages were used for degree days and precipitation $(\mathrm{mm})$ for the period between 1961 and 1990. The climatic measurements were spatially interpolated using local thin plate spline functions (Franke 1982; Mitas \& Mitasova 1988). To obtain an estimate of the local climatic properties and the local climatic variability relevant for each geographic location, we calculated mean, standard deviation, maximum, and minimum within a $1 \times 1 \mathrm{~km}$ rectangular neighbourhood.

The thermic variables include degree-days and summer frost frequency. Degree-days are calculated as the sum of degrees above a $5^{\circ} \mathrm{C}$ threshold for a whole year (Zimmermann \& Kienast 1999). Summer frost frequency expresses the number of frost events during the frost-sensitive time of the year. A frost event is defined by a fall in temperature below zero if it was preceeded by a period of temperatures $>3{ }^{\circ} \mathrm{C}$ during the frost sensitive period of the year (Bolliger et al. 2000). 
TABLE 1. Morphological and ecological characteristics and Red List status of the six lichen species studied (status after Scheidegger et al. 2002)

\begin{tabular}{|c|c|c|c|c|c|}
\hline Species & $\begin{array}{l}\text { Growth } \\
\text { form }\end{array}$ & $\begin{array}{l}\text { Red List status in } \\
\text { Switzerland }\end{array}$ & $\begin{array}{l}\text { Main altitudinal range } \\
(\mathrm{min} / \mathrm{max})[\mathrm{m} \text { a.s.l. }\end{array}$ & Habitat & Colonized tree species \\
\hline Cetrelia cetrarioides & Foliose & Near threatened & $1000-1600$ & $\begin{array}{l}\text { Relatively oceanic sites with high } \\
\text { precipitation rates, often in old } \\
\text { woodlands but also on free-standing } \\
\text { trees }\end{array}$ & $\begin{array}{l}\text { Deciduous trees, mainly } \\
\text { Acer pseudoplatanus and } \\
\text { Fagus silvatica }\end{array}$ \\
\hline Graphis scripta & Crustose & Least concern & $600-1000$ & $\begin{array}{l}\text { Moderately to deeply shadowed smooth } \\
\text { bark in forests and on free-standing } \\
\text { trees at humid sites }\end{array}$ & $\begin{array}{l}\text { Deciduous trees, mainly } \\
\text { Fagus silvatica and } \\
\text { Fraxinus excelsior }\end{array}$ \\
\hline $\begin{array}{l}\text { Hypogymmia } \\
\text { physodes }\end{array}$ & Foliose & Least concern & $1000-1600$ & $\begin{array}{l}\text { On siliceous rocks, trees and other } \\
\text { acidic substrata, over a wide range of } \\
\text { habitats }\end{array}$ & $\begin{array}{l}\text { Conifers and deciduous } \\
\text { trees, mainly Picea abies } \\
\text { and Abies alba }\end{array}$ \\
\hline Lecanora cadubriae & Crustose & Least concern & $1000-1600$ & $\begin{array}{l}\text { Cold, relatively continental sites, mainly } \\
\text { in forests }\end{array}$ & $\begin{array}{l}\text { Conifers, mainly Larix } \\
\text { decidua and Picea abies }\end{array}$ \\
\hline Letharia vulpina & Fruticose & Least concern & $1000-1600$ & $\begin{array}{l}\text { Cold, well lit sites on very acidic bark in } \\
\text { forests and open habitats }\end{array}$ & $\begin{array}{l}\text { Conifers, mainly Larix } \\
\text { decidua and Pinus cembra }\end{array}$ \\
\hline Lobaria pulmonaria & Foliose & Vulnerable & $1000-1600$ & $\begin{array}{l}\text { Relatively oceanic sites with high } \\
\text { precipitation rates, often in old } \\
\text { woodlands but also on free-standing } \\
\text { trees }\end{array}$ & $\begin{array}{l}\text { Deciduous trees, mainly } \\
\text { Acer pseudoplatanus and } \\
\text { Fagus silvatica }\end{array}$ \\
\hline
\end{tabular}


TABLE 2. Description of climatic variables used in regression models

\begin{tabular}{|c|c|c|c|c|}
\hline Climatic variable & Abbreviation & Minimum & Maximum & Mean \\
\hline Summer frost frequency $(0 \cdot 01$ nday $)$ & Sfro & 0 & 8154 & $92 \cdot 3$ \\
\hline Degree day sum (day^deg*10) & Dgd & 0 & 3712 & $1728 \cdot 8$ \\
\hline Yearly precipitation sum $\left(0.01 \mathrm{~mm} \mathrm{yr}^{-1}\right)$ & Nann & 4326 & 5189 & $14135 \cdot 7$ \\
\hline Water budget in July $\left(0.01 \mathrm{~mm} \mathrm{mth}^{-1}\right)$ & $\mathrm{Wb}_{\mathrm{Jul}}$ & -42 & 265 & 74.5 \\
\hline \multirow[t]{2}{*}{ Radiation in March and July [kJ day ${ }^{-1}$ (monthly avg.)] } & $\mathrm{R}_{\text {Mar. }}, \mathrm{R}_{\text {Jul. }}$ & $\mathrm{R}_{\text {Mar. }}: 0$ & 9578 & $3689 \cdot 2$ \\
\hline & & $\mathrm{R}_{\mathrm{Jul}}: 0$ & 10165 & $6721 \cdot 3$ \\
\hline Gams angle (unitless) & Kig & 47 & 726 & $452 \cdot 7$ \\
\hline
\end{tabular}

Hygric variables include mean yearly precipitation sum and water budget in July. The water budget in July is calculated as the difference between the precipitation sum and the potential evapotranspiration in July. Potential evapotranspiration is calculated from the empirical formula of Turc (1961). For calculation details, see Zimmermann and Kienast (1999).

Measures of continentality include radiation for the months March and July and Gams angle. Potential direct solar radiation was estimated from the empirical formula of Müller (1984). The Gams angle gives a general estimate of landscape-scale weather patterns with sensitivity to regional differences based on precipitation and temperature regimes at given elevations (Zimmermann \& Kienast 1999).

\section{Forest types}

Data for forest types across Switzerland were derived from BFS (BFS 1990/1992). The data has a resolution of $25 \mathrm{~m}$ and relies on 11 geometrically and radiometrically corrected Landsat-5 TM scenes, generated between 1990 and 1992 (BFS 1990/1992). First, the satellite images were classified into forest/non-forest using a maximum likelihood classifier (BFS 1990/ 1992). Second, the 11 Landsat-5 TM scenes were categorized into four forest types: coniferous (90-100\% conifers), mixed coniferous (50-90\% conifers), mixed deciduous (10-50\% coniferous) and deciduous (0-10\% coniferous), also using maximum likelihood classifier (BFS 1990/1992). The classification has an overall accuracy of $91 \cdot 8 \%$ (BFS 1990/1992).

\section{Model fitting}

The dependent variable of the logistic regression models was observed lichen species presence and absence from the SwissLichens database (Tables $1 \& 3$ ). Lichen species presence/absence was geographically intersected with the independent climatic variables (mean, standard deviation, minimum, and maximum) and forest types. This data set was then subjected to the logistic regression (stepwise selection), where thresholds for entry or stay were set at a level of significance of 0.05 and relied on minimal correlation of the variables $(<0 \cdot 5)$ as assessed by a correlation matrix.

\section{Model evaluation}

Accuracy of the predicted lichen models. Confusion matrices were used to evaluate the accuracy of the predicted versus the observed presence or absence of a species. Confusion matrices are $2 \times 2$ cross-tabulations of the proportions of correct model predictions for presence (sensitivity) and absence (specificity) with respect to the observed data (Fielding \& Bell 1997). The matrices may be assessed using a discrete threshold identified to benchmark species presence versus absence, or they may be threshold independent.

Threshold-dependent approaches include the Kappa statistics (Cohen 1960), which identify species presence and absence discretely by measuring the proportion of agreement. A threshold-independent method to assess the degree to which species presence and absence were predicted correctly relied on AUC (Area Under the Curve) statistics derived from ROC (Receiver Operating Characteristics) plots (Fielding \& Bell 1997). Here, we applied a modified version of the AUC, the Gini coefficient (AUC') (Copas 1999). The AUC' takes values between 0 and 1 , where 0 indicates no prediction success and 1 indicates high prediction success for both presence and absence.

Predictive ability of the lichen models. Ideally, an independent data set is used to test a model's predictive ability. Because we did not have such a data set, a tenfold cross-evaluation was applied (Verbyla \& Litvaitis 1989). Cross-validated models were then assessed by $\mathrm{AUC}^{\prime}$ eval values (mean and standard deviation), and compared to the predictions originating from the full calibration data set $\left(\mathrm{AUC}^{\prime}{ }_{\mathrm{cal}}\right)$. $\mathrm{AUC}_{\text {eval }}^{\prime}$ was calculated using SimTest (Zimmermann 2001).

\section{Results}

\section{Model evaluation}

Model $\mathrm{R}^{2}$ for all six lichen species ranged between 0.4 and 0.75 (Table 3 ). The climatic variables included measures related to continentality (radiation, Gams angle), 
TABLE 3. Numbers of observations and quantitative assessments of logistic regression model performance for each lichen species studied

\begin{tabular}{|c|c|c|c|c|c|c|c|c|c|c|c|c|}
\hline \multirow[b]{3}{*}{ Lichen species } & \multirow{2}{*}{\multicolumn{3}{|c|}{$\begin{array}{l}\text { Number of } \\
\text { observations }\end{array}$}} & \multicolumn{4}{|c|}{ Model } & \multirow{2}{*}{\multicolumn{3}{|c|}{$\begin{array}{l}\text { Test statistics } \\
\text { for the calibrated models }\end{array}$}} & \multirow{2}{*}{\multicolumn{2}{|c|}{$\begin{array}{l}\text { Test statistics for } \\
\text { the evaluated } \\
\text { models }\end{array}$}} \\
\hline & & & & & $\begin{array}{r}\text { Bioclim } \\
\text { variabl }\end{array}$ & $\begin{array}{l}\text { latic } \\
\text { les }\end{array}$ & Forest variables & & & & & \\
\hline & Presence & Absence & Total & Thermic & Hygric & Continentality & & $\mathrm{R}_{\text {cal }}^{2}$ (Nagelkerke) & $\mathrm{AUC}_{\mathrm{cal}}$ & $\mathrm{AUC}_{\mathrm{cal}}^{\prime}$ & $\mathrm{AUC}_{\text {eval }}$ & $\mathrm{AUC}_{\text {eval }}^{\prime}$ \\
\hline Cetrelia cetrarioides & 169 & 817 & 986 & $\mathrm{Sfro}_{\mathrm{s}}$ & $\begin{array}{l}\mathrm{Nann}_{\mathrm{s}} \\
\mathrm{WbJu}_{\mathrm{s}} \\
\mathrm{WbJu}_{\text {min }}\end{array}$ & - & $\begin{array}{c}\text { Non-forest } \\
\text { Mixed deciduous } \\
\text { Deciduous }\end{array}$ & 0.54 & $0 \cdot 90$ & $0 \cdot 80$ & $0 \cdot 78++$ & $0 \cdot 56++$ \\
\hline Graphis scripta & 397 & 695 & 1092 & Sfro $_{s}$ & - & $\begin{array}{l}\mathrm{RJul}_{\min } \\
\mathrm{Kig}_{\min }\end{array}$ & - & $0 \cdot 56$ & 0.63 & $0 \cdot 60$ & $0 \cdot 82++$ & $0.63++$ \\
\hline Hypogymnia physodes & 671 & 616 & 1289 & Sfro $_{\mathrm{s}}$ & - & $\mathrm{RJul}_{\max }$ & Coniferous & $0 \cdot 40$ & $0 \cdot 80$ & $0 \cdot 60$ & $0 \cdot 80++$ & $0 \cdot 60++$ \\
\hline Lecanora cadubriae & 66 & 802 & 868 & Sfro $_{\mathrm{s}}$ & $\mathrm{Nann}_{\max }$ & $\mathrm{RJul}_{\max }$ & Non-forest & $0 \cdot 65$ & $0 \cdot 94$ & $0 \cdot 88$ & $0 \cdot 90+$ & $0 \cdot 90++$ \\
\hline Letharia vulpina & 78 & 799 & 877 & $\mathrm{Sfro}_{\mathrm{s}}$ & $\begin{array}{l}\mathrm{WbJu} \\
\mathrm{WbJu}_{\mathrm{max}}\end{array}$ & $\mathrm{Kig}_{\max }$ & - & $0 \cdot 75$ & $0 \cdot 86$ & $0 \cdot 72$ & $0 \cdot 90+$ & $0 \cdot 63+++$ \\
\hline Lobaria pulmonaria & 146 & 824 & 970 & $\begin{array}{l}\operatorname{Dgd}_{m} \\
\text { Sfro }_{\mathrm{s}}\end{array}$ & - & - & Non-forest & 0.55 & 0.90 & $0 \cdot 80$ & $0 \cdot 90+$ & $0 \cdot 80++$ \\
\hline
\end{tabular}

$\mathrm{Sfro}_{\mathrm{s}}=$ standard deviation of summer-frost frequency, $\mathrm{Dgd}_{\mathrm{m}}=$ mean of degree day sum, $\mathrm{WbJum}_{\max }=$ maximum of water budget in July, WbJu $\mathrm{min}_{\mathrm{min}}=\mathrm{mimum}_{\mathrm{m}}$ of

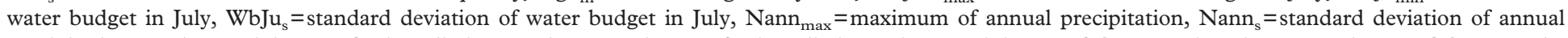

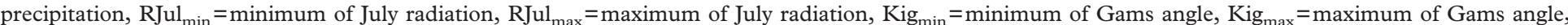
$\mathrm{R}^{2}=$ Nagelkerke's $\mathrm{R}^{2}, \mathrm{AUC}_{\mathrm{cal}}=$ Area Under the Curve for the calibrated model, $\mathrm{AUC}_{\text {eval }}=$ Area under the curve for the evaluated model, $\mathrm{AUC}{ }_{\text {cal }}=\mathrm{Gini}$ coefficient for the calibrated model, AUC' ${ }_{\text {eval }}=$ Gini coefficient for the evaluated model. Statistical tests for the evaluated models: $n=10$, means, standard deviation categorised as $+<0 \cdot 01,++0 \cdot 01-0 \cdot 1,+++>0 \cdot 1$. 
hygric (July water budget, annual precipitation), and thermic factors (summer frost frequency, degree days). Of these variables, the standard deviation, minimum, and maximum were often more important than the means (Table 3). The forest types entering the regressions encompassed mixed deciduous, deciduous, coniferous and non-forest.

For five species models, the thresholdindependent indicator for model accuracy for the full calibration data set $\left(\mathrm{AUC}^{\prime}{ }_{\text {cal }}\right.$ ) ranged between 0.60 and 0.88 , indicating satisfactory to good discrimination between predicted and observed species presence and absence (Table 3). Thus, the pattern of the predictive ability of the lichen distribution models is very similar to the one observed for the model calibrated with the full data set.

\section{Potential spatial distribution of epiphytic lichen species}

The potential spatial distributions of Graphis scripta and Hypogymnia physodes are broad with high probabilities of occurrence in the Jura mountains, the Plateau, and in the Northern and Southern part of the Alps (Fig. 1, Fig. 2B \& C). Hypogymnia physodes and Graphis scripta are both ubiquitous with high probabilities of occurrence in all major bioclimatic ranges of Switzerland, including the Central Alps (Fig. 1, Fig. 2C). Whereas Hypogymnia physodes covers low and higher altitudes, Graphis scripta has low probabilities of occurrence at higher altitudes (Fig. 2B \& C). Cetrelia cetrarioides and Lobaria pulmonaria exhibit high probabilities of occurrence throughout the Jura mountains, and the Northern and Southern Alps with likelihood of lower occurrence on the Plateau (Fig. 1, Fig. 2A \& F). This indicates that these species occur predominantly at higher elevations (montane zone, $<1500 \mathrm{~m}$ a.s.1.) in suboceanic climates (Northern Alps, Jura). The predicted and observed spatial distributions of Letharia vulpina are restricted to the higher elevations of the Central Alps (Fig. 1, Fig. 2E). Similarly, empirical evidence suggests that Lecanora cadubriae is also primarily observed in the Central Alps (Fig., 1, Fig. 2D), but, in contrast to Letharia vulpina, however, this species is also observed and predicted to occur in the Northern Alps, although with rather low probabilities of occurrence. (Fig. 1, Fig. 2D).

\section{Discussion}

\section{Spatial predictive models for lichen species}

We successfully predicted the occurrence of lichen species as a function of exogeneous environmental characteristics. The approach assesses statistical relationships between the response variable and the explanatory variables to predict the species in previously not sampled geographical space. For inconspicuous or rare species, this often means that the data for the response variable originates from different sampling strategies in order to increase the number of observations to allow modelling. For our approach, we combined data from a systematic design and from purposive data sampling. Although the focus of this paper was to test how well the data extrapolated to unsampled regions, future research should assess possible effects of the data sampling strategies. A recent paper by Edwards et al. (2006) provides evidence that the selection of explanatory variables as well as the prediction accuracy of a model may depend on the sampling strategy of the dependent variable.

It is typically assumed in spatial distribution models that a few parsimonious environmental variables suffice to predict species distributions (e.g., climate, topography) (Bolliger et al. 2000; Bolliger et al. 2000; Guisan \& Theurillat 2000; Thuiller et al. 2003; Edwards et al. 2006). Among environmental drivers, climate is referred to as a resource predictor and has been used extensively for predicting species distributions (Bolliger et al. 2000; Guisan \& Hofer 2003) at the landscape and the continental scale (Holdridge 1947; Woodward 1987). The simplification of predicting species distributions using only a few environmental variables holds true in environments such as those the Alps where the vegetation is likely 
A
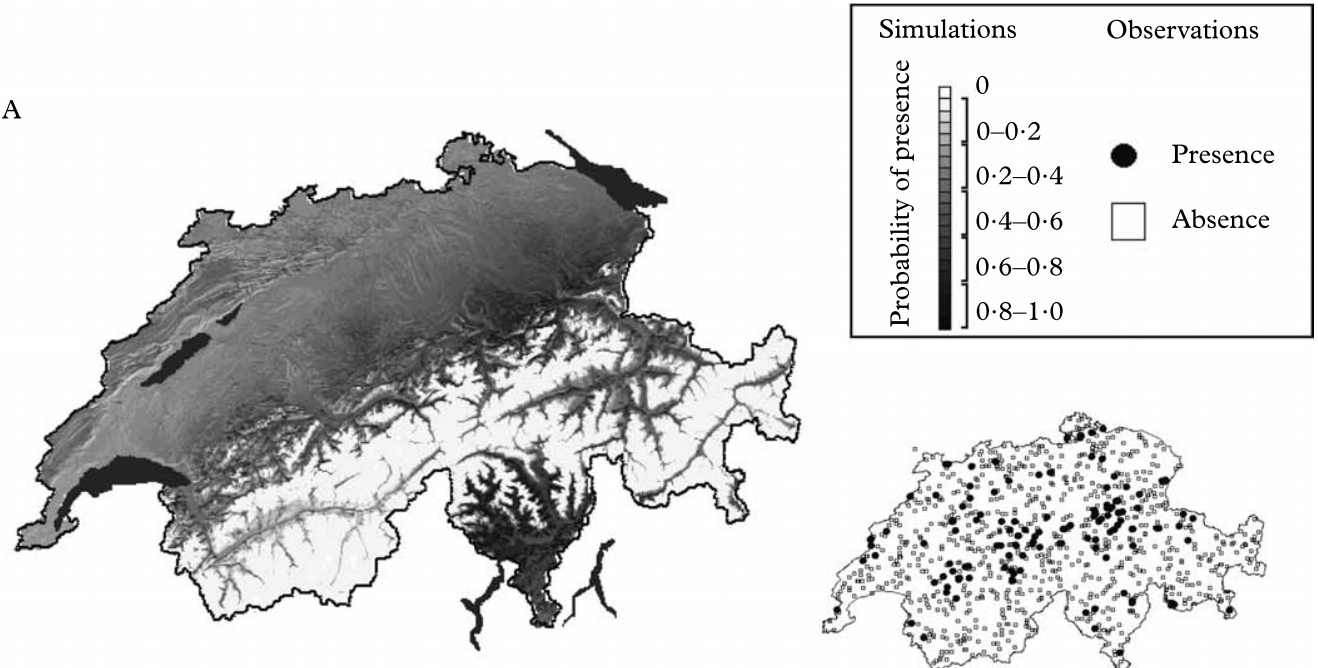

B
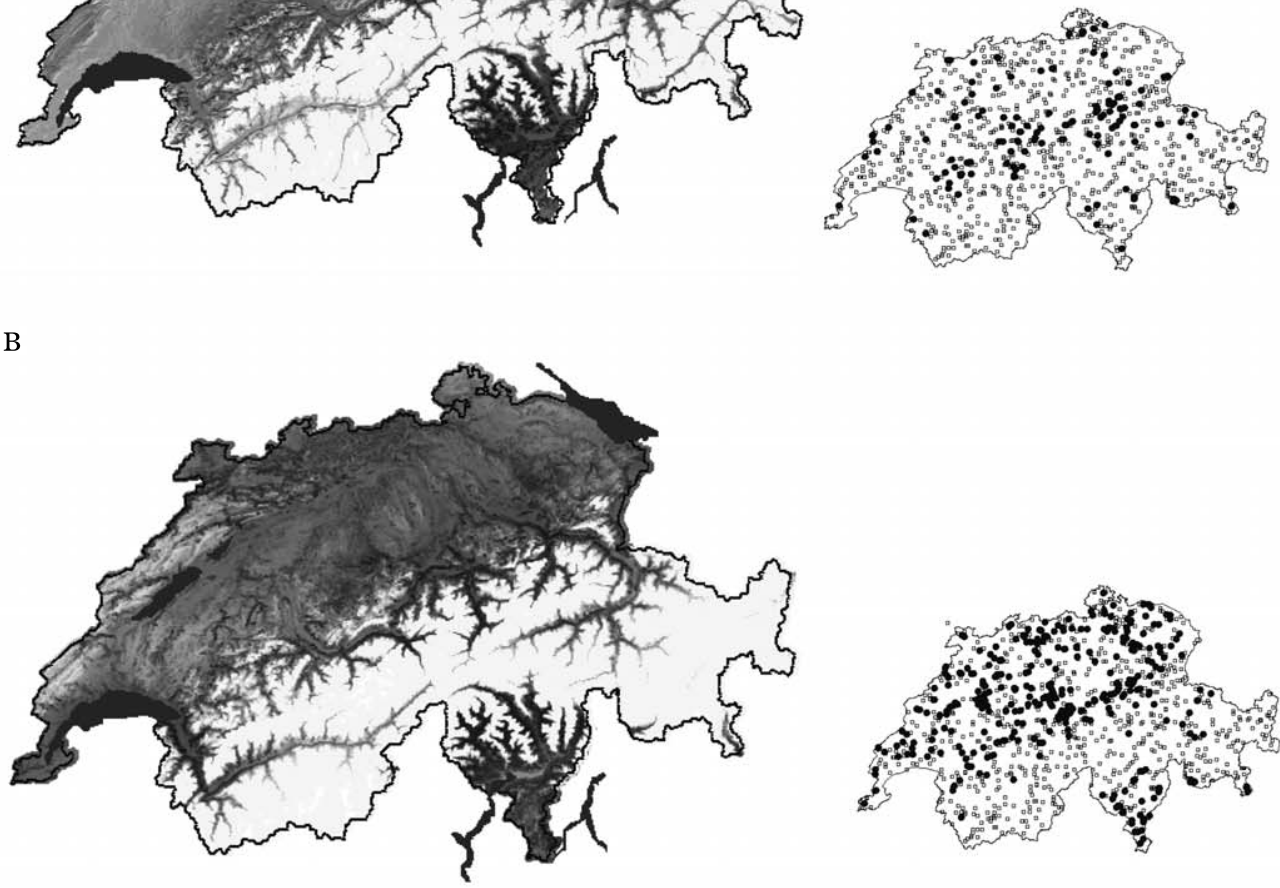

c
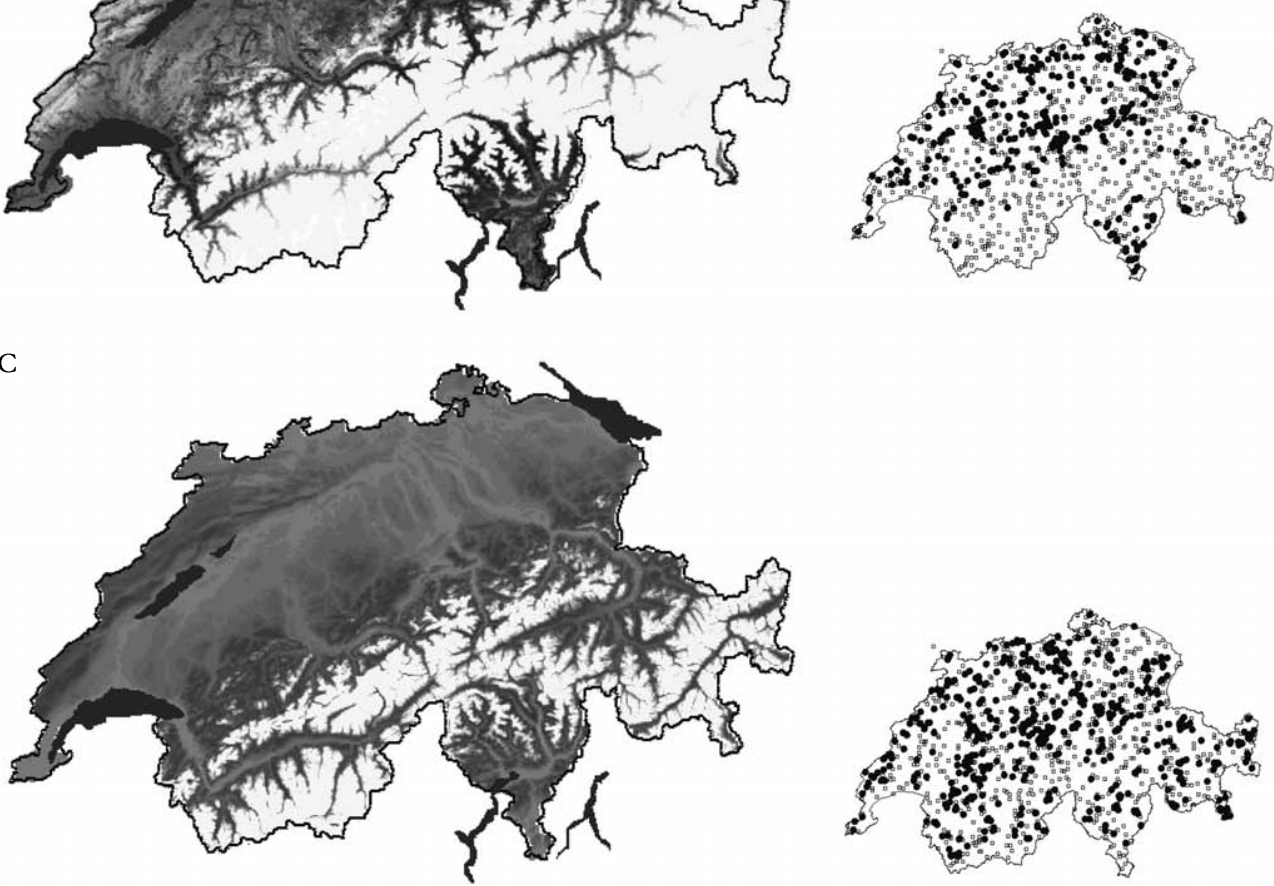

FIG. 2. A-F. Potential habitat distribution maps for six epiphytic lichen species. A, Cetrelia cetrarioides; B, Graphis scripta; C, Hypogymnia physodes. 

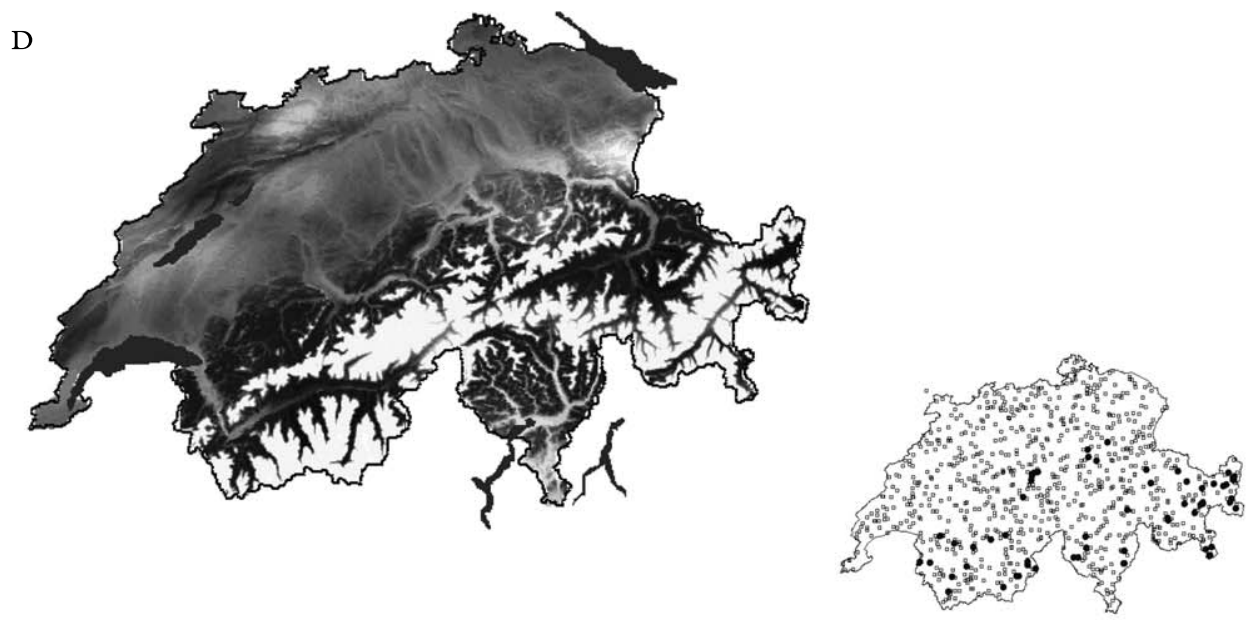

$\mathrm{E}$
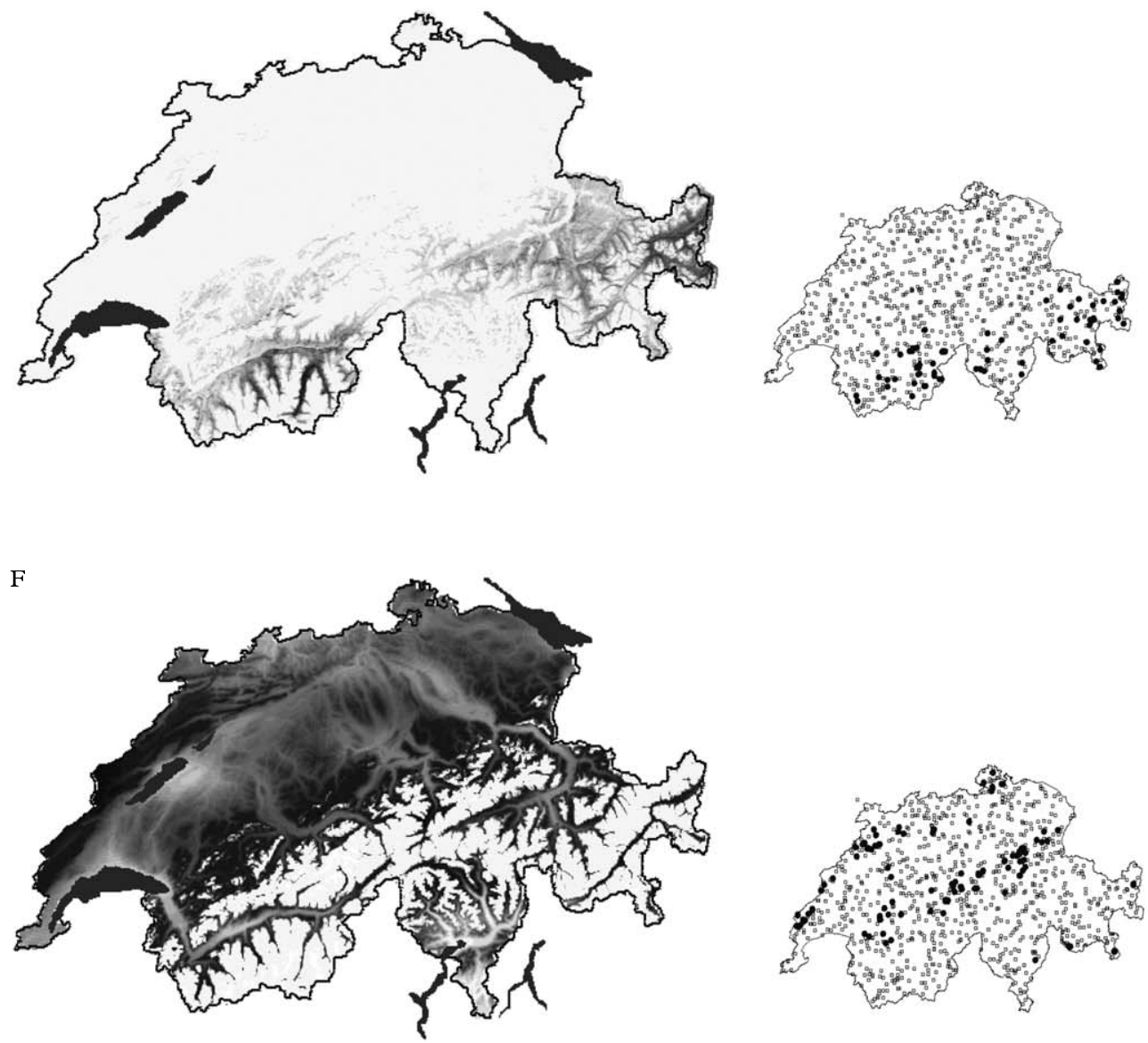

FIG. 2. Continued. D, Lecanora cadubriae; E, Letharia vulpina; F, Lobaria pulmonaria. 
to be primarily driven by environmental variables (e.g., temperature) at the mesoscale. Certainly, the credibility of the models and the resulting plausibility of the predicted spatial lichen distributions depend largely on the availability and quality of the input data sets used for model calibration. The climatic variables used here rely on about 400 climate stations across Switzerland. Most of the stations are located at lower elevations. This bias is addressed and partly compensated for by applying a high-resolution $25 \mathrm{~m}$ DEM that accounts for the complex topography in a mountainous area. All climatic variables are long-term climatic records (30 year monthly normals) that have been used in various studies in Switzerland (e.g. global change: Zimmermann \& Kienast 1999; Bolliger et al. 2000; Bolliger et al. 2000).

Interestingly, our results suggest that climatic minima, maxima, and standard deviations are of greater relevance in explaining species occurrences than mean values. However, by using climate variables with a $1 \mathrm{~km}^{2}$ resolution, local-scale climatic characteristics cannot be accounted for. For example, in the northern-most part of Switzerland there are some isolated occurrences of Lobaria pulmonaria which are not accurately predicted by the model. Overall, this region is characterized by a dry and warm local climate quite untypical for Lobaria pulmonaria. However, the species occurs in locally more humid climates such as ravines, local topographic variability or coppice with standard forests, which favour Lobaria pulmonaria populations. These particular local climatic conditions cannot be assessed with geographically aggregated variables. On the other hand, the occurrence of species with a limited regional distribution is likely to be overestimated by the simulation presented here. Letharia vulpina and Lecanora cadubriae are both frequent in subalpine forests in continental regions of the Alps but were not reported from the Jura mountains. For Letharia vulpina the simulation correctly predicts high probabilities of presence in the Central Alps of the cantons of Valais and Graubünden. Some rather isolated regions in the Northern and Southern Alps were correctly predicted. However, the extremely small and scattered islands in the Jura mountains where the simulation predicts a low probability of presence for the species at the highest altitudes, the species probably does not occur owing to chorological reasons (SwissLichens). The simulation of Lecanora cadubriae distribution predicts rather high probabilities of presence on the Plateau and on the Jura mountains. Generally, Lecanora cadubriae has a distribution pattern that is similar to Letharia vulpina except for more outposts in the northern Alps. However, this species does not occur on the Plateau and the Jura mountains, for chorological, rather than for climatological reasons.

Epiphytic lichens are well known to be sensitive to host tree species and forest structure and management (Barkman 1958; Dietrich \& Scheidegger 1996; Uliczka \& Angelstam 1999; Ihlen et al. 2001; Johansson \& Ehrlén 2003; Pykälä 2004). Although the forest types used here characterized very crudely the habitat requirements of the lichen species examined, for four out of the six species the forest types were important for modelling the species distributions. The simulation gives an accurate prediction of the distribution of Hypogymnia physodes and Graphis scripta, two species that are good colonizers with a broad tree species spectrum.

Another limitation of the regression modelling approach is that endogeneous drivers such as biotic interactions (e.g., competition), feedback, or various aspects of species-specific life-history attributes (e.g., dispersal ability) are not usually accounted for by spatial regression models (Bolliger et al. 2000; Guisan \& Zimmermann 2000). Thus, the modelling approach does not consider species specific life-history attributes of the biota. In addition, it is suggested that lichen responses to climatic conditions depend on the physiological state of the lichen (Scheidegger \& Schroeter 1995). Models could be improved by accounting for local forest structure, composition and disturbance history (Kalwij et al. 2005; Werth et al. 2006; Werth et al. 2006), or life-history attributes, but such data are not usually available in the required resolution or scale. 
This constraint is rather common in spatial distribution modelling. Although these limitations may lead to truncated response curves (Hirzel et al. 2001), or to inconsistent model performances that vary across geographical space, most approaches assess species distributions using surrogates (e.g., temperature). This is particularly true for large-scale study areas with strong environmental gradients (e.g., Switzerland with strong altitudinal gradients) which drive major vegetation patterns (Zimmermann \& Kienast 1999; Bolliger et al. 2000). The interpretation of the distribution maps are thus a large-scale assessment without claiming detailed interpretations on life-history details.

Model performance using threshold independent indicators suggests that the spatial distribution of the biotic input data has a significant effect on the statistical accuracy and the predictive success of the output. This effect is independent of the number of lichen observations used for model calibration. Letharia vulpina, with 78 observations and the rarest species considered, is a species restricted to the continental high-elevation range and exhibits the highest model performance compared with the other five species (Table 3). Discrimination between presence and absence of a geographically defined species distribution pattern is predicted better than for a widely distributed species. Correspondingly, the Gams angle, a continentality-specific variable becomes important with Letharia vulpina. Furthermore, the predicted distribution of Letharia vulpina is presumably less impacted by any human disturbances since this species occurs in the subalpine part of the central and southern Alps which exhibit rather low human populations. The predicted niche of this species may thus approach its realised niche under current climatic conditions. In contrast, the modelled niche of the threatened Lobaria pulmonaria (Scheidegger \& Clerc 2002), although clearly defined by thermic variables (degree days, summerfrost), has been affected by human activities such as forest management, especially in the lowlands (Clerc et al. 1992). Thus, some areas with certain combinations of environmental variables under which this species could occur are presumably not occupied at the moment. Without any human activities we assume that Lobaria pulmonaria would have higher probabilities of occurrence on the Plateau (more upland regions).

\section{Implications for lichen conservation and management}

While high-quality data are often available throughout a study area for many conspicuous taxa, at least in non-tropical and socalled developed countries, for less prominent taxa such as lichens data are often sparse. Even regional distributions might not be well known because of the lack of lichenologists in many countries (Wolseley 1995). The lack of knowledge of species distributions may prevent their allocation to red-list categories defined by IUCN (2001). For example, the extent of occurrence in a region and its temporal trend are very important measures for assessing the conservation status of a species. However, measuring the extent of occurrence by a minimum convex polygon as proposed by IUCN (2001) can result in poor estimates if the geographic distribution of the species is not well sampled. Furthermore, in a geographically highly structured country such as Switzerland, with very different climatic regions and strong environmental gradients where suitable habitat patches are often quite distant from each other, the estimates of the extent of occurrence by minimum convex polygons are much too large. This may lead to an inappropriately low red-list status of the species (see also Burgman \& Fox 2003). In such cases, niche-based models such as developed here may yield more realistic estimates of the extent of occurrence than the actual data, provided that the thresholds to transfer the probability maps into binary maps are chosen sensibly.

We thank Marc Kéry and Michael Lütolf for helpful comments on earlier drafts of this manuscript. This research was funded by the European Union project BioScene (EVK2-2001-00354) and the project "Biotopschutz", supported by the Swiss Federal Office of the Environment, Forests and Landscape. 


\section{REFERENCES}

Allen, P. A., Li, B.-L. \& Charnov, E. L. (2001) Population fluctuations, power laws, and mixtures of lognormal distributions. Ecology Letters 4: 1-3.

Barkman, J. J. (1958) Phytosociology and Ecology of Cryptogamic Epiphytes. Assen: Van Gorcum \& Comp. N.V.

Bartlein, J. P., Prentice, I. C. \& Webb III, T. (1986) Climatic response surface from pollen data for some eastern North American taxa. Fournal of Biogeography 13: 35-57.

Berg, A., Gärdenfors, U. \& von Proschwitz, T. (2004) Logistic regression models for predicting occurrence of terrestrial molluscs in southern Swedenimportance of environmental data quality and model complexity. Ecography 27: 83-93.

BFS (1990/1992) Waldmischgrad. Bundesamt für Statistik, Servicestelle GEOSTAT.

Bolliger, J., Kienast, F. \& Bugmann, H. (2000) Comparing models for tree distributions: concept, structures, and behavior. Ecological Modelling 134: 89-102.

Bolliger, J., Kienast, F. \& Zimmermann, N. E. (2000) Risks of global warming on montane and subalpine forests in Switzerland. Regional Environmental Change 1: 99-111.

Bonn, A. \& Schröder, B. (2001) Habitat models and their transfer for single and multi-species groups: a case study of carabids in an alluvial forest. Ecography 24: 483-496.

Bowker, G. C. (2000) Mapping biodiversity. International fournal of Geographic Information Systems 14: 739-754.

Brown, D. G. (1994) Predicting vegetation types at treeline using topography and biophysical disturbance variables. Fournal of Vegetation Science 5: 641-656.

Burgman, M. A. \& Fox, J. C. (2003) Bias in species range estimates from minimum convex polygons: implications for conservation and options for improved planning. Animal Conservation 6: 19-28.

Clerc, P., Scheidegger, C. \& Ammann, K. (1992) Liste rouge des macrolichens de la Suisse. Botanica Helvetica 102: 71-83.

Cohen, J. (1960) A coefficient of agreement for nominal scales. Educational and Psychological Measurement 20: $37-46$.

Copas, J. (1999) The effectiveness of risk scores: the logit rank plot. Fournal of the Royal Statistical Society Series C-Applied Statistics 48: 165-183.

Dietrich, M. \& Scheidegger, C. (1996) Diversität und Zeigerwerte von epiphytischen Flechten der häufigsten Baumarten: Ein methodischer Ansatz zur Beurteilung von Umweltveränderungen im Wald und im Freiland. Botanica Helvetica 106: 85-102.

Dietrich, M., Stofer, S., Scheidegger, C., Frei, M., Groner, U., Keller, C., Roth, I. \& Steinmeier, C. (2000) Data sampling of rare and common species for compiling a Red List of epiphytic lichens. Forest, Snow and Landscape Research 75: 369-380.

Dirnböck, T., Dullinger, S. \& Grabherr, G. (2003) A regional impact assessment of climate and land-use change on alpine vegetation. Fournal of Biogeography 30: 401-417.

Dullinger, S., Dirnböck, T. \& Grabherr, G. (2003) Patterns of shrub invasion into high mountain grasslands of the Northern calcareous Alps, Austria. Arctic, Antarctic, and Alpine Research 35: 434-441.

Dullinger, S., Dirnböck, T., Greimler, S. \& Grabherr, G. (2003) A resampling approach to evaluate effects of summer farming on subalpine plant species diversity. Fournal of Vegetation Science 14: 243-252.

Easterling, W. E., Brandle, J. R., Hays, C. J., Guo, Q. \& Guertin, D. S. (2001) Simulating the impact of human land-use change on forest composition in the Great Plains agroecosystems with the Seedscape model. Ecological Modelling 140: 163-176.

Edwards, T. C., Cutler, D. R., Zimmermann, N. E., Geiser, L. \& Moisen, G. G. (2006) Effects of sample survey design on the accuracy of classification tree models in species distribution models. Ecological Modelling 199: 132-141.

Edwards, T. C., Cutler, R., Zimmermann, N. E., Geiser, L. \& Alegria, J. (2005) Model-based stratification for enhancing the detection of rare ecological events. Ecology 86: 1081-1090.

Fielding, A. H. \& Bell, J. F. (1997) A review of methods for the assessment of prediction errors in conservation presence/absence models. Environmental Conservation 24: 38-49.

Franke, R. (1982) Smooth interpolation of scattered data by local thin plate splines. Computers and Mathematics with Applications 8: 237-281.

Guisan, A. \& Hofer, U. (2003) Predicting reptile distributions at the mesoscale: relation to climate and topography. Fournal of Biogeography 30: 1233-1243.

Guisan, A. \& Theurillat, J.-P. (2000) Equilibrium modelling of alpine plant distributions: how far can we go? Phytocoenologia 30: 353-384.

Guisan, A., Theurillat, J.-P. \& Kienast, F. (1998) Predicting the potential distribution of plant species in an alpine environment. Fournal of Vegetation Science 9: 65-74.

Guisan, A. \& Thuiller, W. (2005) Predicting species distributions: offering more than simple habitat models. Ecology Letters 8: 993-1009.

Guisan, A. \& Zimmermann, N. E. (2000) Predictive habitat distribution models in ecology. Ecological Modelling 135: 147-186.

Hampe, A. (2004) Bioclimate envelope models: what they detect and what they hide. Global Ecology and Biogegraphy 13: 469-476.

Hirzel, A. H., Helfer, V. \& Metral, F. (2001) Assessing habitat-suitability models with a virtual species. Ecological Modelling 145: 111-121.

Holdridge, L. R. (1947) Determination of world plant formations from simple climatic data. Science 105: 367-368.

Ihlen, P. G., Gjerde, I. \& Saetersdal, M. (2001) Structural indicators of richness and rarity of epiphytic lichens on Corylus avellana in two different forest 
types within a nature reserve in south-western Norway. Lichenologist 33: 215-229.

Johansson, P. \& Ehrlén, J. (2003) Influence of habitat quantity, quality and isolation on the distribution and abundance of two epiphytic lichens. Fournal of Ecology 91: 213-221.

Kadmon, R. \& Heller, J. (1999) Modelling faunal responses to climatic gradients with GIS: land snails as a case study. Fournal of Biogeography 25: 527-539.

Kalwij, J. M., Wagner, H. H. \& Scheidegger, C. (2005) Effects of stand-level disturbances on the spatial distribution of a lichen indicator. Ecological Applications 15: 2015-2024.

Lavergne, S., Thuiller, W., Molina, J. \& Debussche, M. (2005) Environmental and human factors influencing rare plant local occurrence, extinction and persistence: a 115-year study in the Mediterranean region. Fournal of Biogeography 32: 799-811.

Maina, G. G. \& Howe, H. F. (2000) Inherent rarity in community restoration. Conservation Biology 14: 1335-1340.

Martinez, I., Carreno, F., Escudero, A. \& Rubio, A. (2006) Are threatened lichen species wellprotected in Spain? Effectiveness of a proteced area network. Biological Conservation 133: 500-511.

McKenzie, D., Peterson, D. W., Peterson, D. L. \& Thornton, P. E. (2003) Climatic and biophysical controls on conifer species distributions in mountain forests of Washington State, USA. Fournal of Biogeography 30: 1093-1108.

Mitas, L. \& Mitasova, H. (1988) General variational approach to the interpolation problem. Computer Mathematics with Applications 16: 983-992.

Mladenoff, D. J., Sickely, T. A., Haight, R. G. \& Wydeven, A. P. (1995) A regional landscape analysis and prediction of favorable gray wolf habitat in the northern Great Lakes region. Conservation Biology 9: 279-294.

Müller, H. (1984) Zum Strahlungshaushalt im Alpenraum. Zürich: Eidg. Techn. Hochschule Zürich.

Pykälä, J. (2004) Effects of new forestry practices on rare epiphytic macrolichens. Conservation Biology 18: $831-838$.

Scheidegger, C. \& Clerc, P. (2002) Rote Liste der gefährdeten Arten der Schweiz. Baum- und erdbewohnende Flechten. In Hrsg. Bundesamt für Umwelt, Wald und Landschaft BUWAL, Bern. Eidgenössische Forschungsanstalt WSL, Birmensdorf: Conservatoire et Jardin botaniques de la ville de Genève CJBG.

Scheidegger, C., Clerc, P., Dietrich, M., Frei, M., Groner, U., Keller, C., Roth, I., Stofer, S. \& Vust, M. (2002) Rote Liste der gefährdeten baum- und erdbewohnenden Flechten der Schweiz. Bern. Bundesamt für Umwelt, Wald und Landschaft (BUWAL) Bern, Eidgenössische Forschungsanstalt WSL, Birmensdorf: Conservatoire et Jardin botaniques de la ville de Genève CJBG.

Scheidegger, C. \& Schroeter, B. (1995) Effects of ozone fumigation on epiphytic macrolichens: ultrastruc- ture, $\mathrm{CO}_{2}$ gas exchange and chlorophyll fluorescence. Environmental Pollution 88: 345-354.

Segurado, P. \& Araujo, M. B. (2004) An evaluation of methods for modelling species distributions. Fournal of Biogeography 31: 1555-1568.

Statistisches Jahrbuch der Schweiz (1997). Zürich: Verlag Neue Zürcher Zeitung.

Stofer, S., Scheidegger, C., Dietrich, M., Frei, M., Groner, U., Keller, C., Roth, I., Sutter, F. \& Zimmermann, E. 2003 SwissLichens. http:// www.swisslichens.ch.

Thuiller, W., Araujo, M. B. \& Lavorel, S. (2003) Generalized models vs. classification tree analysis: predicting spatial distributions of plant species at different scales. Fournal of Vegetation Science 14: 669-680.

Thuiller, W., Araujo, M. B. \& Lavorel, S. (2004) Do we need land-cover data to model species distributions in Europe? Fournal of Biogeography 31: 353-361.

Turc, L. (1961) Evaluation des besoins en eau d'irrigation, évapotranspiration potentielle, formule simplifié et mise à jour. Annales agronomiques 12: $13-49$

Uliczka, H. \& Angelstam, P. (1999) Occurrence of epiphytic macrolichens in relation to tree species and age in managed boreal forest. Ecography 22: 396-405.

Verbyla, D. L. \& Litvaitis, J. A. (1989) Resampling methods for evaluation classification accuracy of wildlife habitat models. Environmental Management 13: $783-787$.

Werth, S., Wagner, H. H., Gugerli, F., Holderegger, R., Csencsics, C., Kalwij, J. M. \& Scheidegger, C. (2006) Quantifying dispersal and establishment limitation in a population of an epiphytic lichen. Ecology 87: 2037-2046.

Werth, S., Wagner, H. H., Holderegger, R., Kalwij, J. M. \& Scheidegger, C. (2006) Effect of disturbances on the genetic diversity of an oldforest associated lichen. Molecular Ecology 15: 911-921.

Wirth, V. (1992) Zeigerwerte von Flechten. In Zeigerwerte von Pflanzen in Mitteleuropa $(\mathrm{H}$. Ellenberg, $\mathrm{H}$. E. Weber, R. Düll, V. Wirth, W. Werner \& D. Paulissen, eds): 215-248.

Wolseley, P. A. (1995) A global perspective on the status of lichens and their conservation. Mitteilungen der Eidgenössischen Forschungsanstalt für Wald, Schnee und Landschaft 70: 11-27.

Woodward, F. I. (1987) Climate and Plant Distribution. Cambridge: Cambridge University Press.

Zimmermann, N. E. (2001) SimTest. WSL, Birmensdorf: http:/www.wsl.ch/staff/niklaus.zimmermann/ programs/fort $10-1 . h t m l$.

Zimmermann, N. E. \& Kienast, F. (1999) Predictive mapping of Alpine grasslands in Switzerland: species versus community approach. Fournal of Vegetation Science 10: 469-482. 